\title{
Perceived Challenges of Using Web-Based Library Services by Students in Prof. Festus Aghabgo Nwako Library, Nnamdi Azikiwe University, Awka, Nigeria
}

\author{
Esther Ekene Aghauche1, Obiora Kingsley Udem ${ }^{2}$ \& Emeka Kingsley Ogalanya ${ }^{3}$ \\ Department of Library and Information Science, Nnamdi Azikiwe University, \\ Awka $a^{1,2,3}$ \\ aghaucheesther@yahoo.com/ee.aghauche@unizik.edu.ng1,ok.udem@unizik.edu.ng² \\ Abstract
}

Purpose: This study investigated the challenges confronting the use of web-based library services in Prof. Festus Aghagbo Nwako Library, NnamdiA zikiwe University, Awka.

Methodology: The study adopted descriptive survey research design. The population comprised of 4,529 registered student users of the library and the sample size was 200 students accidentally selected while using the library. Questionnaire was used as the instrument for data collection and the data collected were analyzed using mean.

Findings: The result revealed that challenges such as lack of awareness of available web-based services, lack of fund and high cost of Internet services among others were confronting the use of webbased services in the library.

Implications: lack of awareness of available web-based library services as major challenge to the use of the services shows that students were not aware of these services hence the need for academic libraries to market their web-based services.

Value/Originality: The study's educational value rest on the recommendations that the library should create awareness of available web-based services andthe university authority should provide more funds to enable the library to fully upgrade its web-based services so that a true virtual experience could be derived from the use of these services.

Keywords: Library services, Web basedLibrary services, Information Literacy, NnamdiAzikiweUniversity Awka, Nigeria.

Paper type: Empirical

\section{Introduction}

Developments in ICT have brought revolutionary changes in the modes and methods by which library users seek, access and communicate information. The advent of the Internet has brought about, unprecedented flow of information such that the format in which information is served is rich and diverse. The access to digital information resources and remote access to technology has changed users' needs and therefore library's objectives and services. In other words, users' needs are the main reason for change in library services. The library has adapted the online platform to meet users' needs. This is because users today are accustomed to the dynamic and interactive nature of the web, as well as social networking tools. Many of them now use web tools to find the information they need (Wang, 2009).

According to Liu (2008) academic library web sites/web pages are libraries virtual presentation to the world. These virtual spaces have evolved rapidly over the years and the dynamic or interactive web sites, encourages user participation. Hence, the academic libraries, particularly the University Libraries in Nigeria today, are improving their service base especially with the application of Information Technology for access and delivery of e-content to their clients. In this process they are also adapting to the change and altering their image, by executing new functions and providing varieties of services in an evolving continuum.

A library web site can play different roles in the delivery of web-based services, in fact it is the major tool used by libraries to provide their webbased services. It can serve as a workstation where a user finds databases, electronic texts, and the online catalog. It is a way to make library-made products available, it is used as a window to the WWW by making Internet resources available on a selective 
basis, and it is a communication tool where information about services, people, facilities and collections can be found. All publicly accessible web sites collectively constitute the WWW. Today, libraries can treat their web sites as a significant point of user contact and as a way of compensating for decreases in traditional measures of library use.

The ability to provide library services on the web, has also created tremendous influence in the transformation of libraries as knowledge resource centers, rather than storehouses of print media. The impact of this change is all-pervasive and affects all the aspects of library operations, information resources and services, staff skill requirements, and users' expectations. The accelerating pace of technological developments has tremendously increased the ability to access, store, and process, communicate, and deliver information services to the desk-tops of the libraries' clients through web-based services.

Web-based library services are simply library services provided using the Internet as a medium and library website as a gateway with the help of integrated library management system. Tella and Issa(2011) describe services as that which is intangible, which cannot be stored up or mass produced. In essence, services are instantly perishable, and come into existence at the time they are bought and consumed. This definition indicates that service is time based; that is, service is produced and consumed instantly. Web-based services provide services to users in real time such that users are served whenever and where ever they might require it.

Availability of web-based library services is simply the presence or absence of core library services from their websites. This implies that the mere presence of library websites is not a guarantee of the availability of web-based library services. Availability of web-based services enables library users to have access to information resources just like in traditional library but online. According to Bhatnagar (2005), library service on the internet possesses the same qualities as traditional references: accuracy, promptness, courtesy, an understanding of the information need. It provides users with the convenience of accessing information in their own time, saving them traveling cost and time. The availability of these services is not constrained by the traditional opening hours but can be offered on a 24-hour, seven-days-a-week basis known as 24/7. As

102 | P a g e libraries continue to make greater use of the Internet, librarians now use websites as a means to provide web-based library and information services, as well as facilitate access to both print and non-print resources. All these are made possible through the use of the library website.

As libraries aspire to remain relevant as suppliers of information that attract and engage their patrons, embracing web-based services has become almost synonymous with their overall success. Libraries now offer a new virtual entrance to their services. The library Web services allow students, lecturers, and researchers to visit the library website through the library Uniform Resource Locator (URL) and access the library collections and facilities. Libraries also provide links for other online resources connecting millions of library users in the academic community.

Libraries face various challenges when it comes to availability and use of web-based library services. They may range from lack of fund, to cost of ICT equipment, lack of technical skill, illiteracy in the use of the computer and other ICT infrastructure, cost and low quality of Internet connectivity by telecommunication service providers, lack of trained library staff, poorly designed website and non-existence of digitization policy. To remain relevant, libraries are evolving strategies to overcome these challenges, which may include improved funding, training of staff among others.

\section{Statement of Problem}

Web-based library services are simply library services provided using the Internet as a medium and library website as a gateway with the help of integrated library management system. Availability of web-based services enables library users to have access to information resources just like in traditional library but online. Library service on the internet possesses the same qualities as traditional references: accuracy, promptness, courtesy, an understanding of the information need. It provides users with the convenience of accessing information in their own time, saving them traveling cost and time. The availability of these services is not constrained by the traditional opening hours but can be offered on a 24-hour, seven-days-a-week basis known as 24/7.

Despite the availability of library websites in most Nigerian Universities, a good number of them are static. In other words, they are not 
interactive and dynamic. It appears from the literature that most academic libraries have websites, but do not provide web-based services, and those that provide web-based services are often not utilized by students. It is in view of this, that it becomes imperative to determine the challenges of using web-based library services in Professor Festus Aghagbo Nwako library, Nnamdi Azikiwe University, Awka.

\section{Purpose of the Study}

The study has the following objectives:

1. To determine perceived challenges facing the use of web-based library services in Prof. Festus AghagboNwako library, NnamdiAzikiwe University, Awka.

2. To suggest strategies that could be used to remedy these challenges.

Two research questions guided the study:

1. What are the perceived challenges facing the use of web-based library services in Prof. Festus AghagboNwako library, NnamdiAzikiwe University, Awka?

2. What are the strategies that could be used to remedy these challenges?

\section{Review of Literature}

Although the growth of ICT and change in information seeking behavior of users have forced libraries to adopt and modify their service pattern. These adoption and modification of services pattern has not been an easy process. Despite the many benefits of web-based library services; there are some challenges when it comes to using these services on the web.

The design of the library website is a major challenge, when it comes to provision and utilization of web-based library resources. This is because a poorly designed website will not only be unattractive to users but will also make it difficult to access and navigate the information resources. According to Gbaje and Kotso (2014) poorly designed library website will not improve the visibility of the library neither will it promote what the library has to offer. Therefore, designing an effective library website that attracts as well as retains library users has become an important task for all academic libraries.

Also the dynamics of user needs make it difficult to create a web system that will align with each individual preference. Ogunsola and Okusaga (2008) noted that before web-based library

103 | P a g e services can take place, there is much to be done; there is need to create electronic information systems that match individual patterns of thinking and learning in other to produce the kind of productivity expected. This can be quiet challenging since user needs vary and changes all the time. This is a major challenge as a system created for a user now can become obsolete the next minute due to change in technology and user needs

Also, it should be noted that library resources are very expensive and as the cost of these resources keeps increasing, it is shocking to note that so is the funding of libraries being reduced or cut. Abubakar (2011) noted that libraries especially academic libraries in Nigeria are at crossroads. This is because they are operating in an era of dwindling finances where resources (financial and materials) are not forthcoming. Nigerian academic libraries derive the greater part of their funds from the government (both Federal and State). Okiy (2005) noted that of all the different types of libraries in Nigeria, only university libraries have a clearly defined policy of funding, because they are allocated $10 \%$ of the recurrent annual budget of their parent institutions. However, it is regrettable that such monies are not forthcoming as most university administrators tend to flout that decision (Okiy, 2005; Yetunde, 2008).

The situation in private universities also tends to portray a gloomy picture as the story seems to be the same. Yetunde (2008) observed that in most private universities in Nigeria the founder and the board of trustees usually determine the share of university library's budget which in most instances is not adequate. This ugly situation affects the efficiency and effectiveness of their functions.

Again, the high rise in foreign exchange has deterred many academic libraries from acquiring current and relevant titles of e-books, e-journals or subscribe to online databases that will support the academic programs of their parent institutions. Thus the effort of most academic libraries in providing modern information services is thwarted by the existence of the aforementioned problems whose genesis is that of inadequate funding. Also, IT literacy among academic librarians in most libraries is still at the peripheral level. Nok (2006) observed that many staff of university libraries are not computer literate as such they find it difficult to cope with the requirements of the electronic age. 
Furthermore, providing current awareness services to an ICT driven target academic community requires dynamic, innovative, timely and adequate communication technologies (Fatoki, 2005). However, most academic libraries in Nigeria are severely constrained by a number of factors that includes erratic internet services, lack of hardware and software and in most instances the non-availability of the said ICTs in most academic libraries.

In a survey study carried out by Madhusudhan and Nagabhusbanam (2012) on the use of webbased library services in select university libraries, it was discovered that although many academic libraries now have websites, many of these websites provide static articles. That is articles that a user can only read but cannot make any contribution or leave an opinion. This is a major challenge as users prefer dynamic websites where they can through the use of web 2.0 make contributions.

Swaminathan (2012) asserted that intellectual property right is another major challenge facing web-based library service. Libraries require flexible licenses to create archival collections and to transfer contents to new storage technologies for preservation and dissemination legally. Obtaining flexible licenses for electronic information is quite challenging since users can easily gain access to unauthorized digital information. In addition libraries may need to charge users for access to materials which is against their tradition as a non-profit organization.

Finally, another challenge to use of web-based library services is lack of awareness. Kaur (2009) opined that marketing strategies do not just include telling the library clientele what collections and services are being offered but it also contributes to building relationship with library patrons that begins and ends with awareness of the library's users: their values, their concerns, and their needs.

\section{Methodology}

The study adopted descriptive survey design. The population comprised of 4,529 registered student users of the library and the sample size was 200 students accidentally selected while using the library. Questionnaire was used as the instrument for data collection and the data collected were analyzed using mean.

\section{Presentation of Data}

Table 1: Mean ratings of the responses on the perceived challenges facing the use of web-based services in Prof. Festus Aghagbo Nwako Library

\begin{tabular}{llll}
\hline S/N & Challenges & Mean & Decision \\
\hline 1 & Lack of awareness of available web services & 3.3 & Agree \\
2 & Poor internet coverage & 3.3 & Agree \\
3 & High cost of internet services & 3.4 & Agree \\
4 & Unstable power supply & 3.0 & Agree \\
5 & Static and unattractive website & 3.0 & Agree \\
6 & Lack of computer literacy skill & 2.7 & Agree \\
7 & Lack of computer facilities & 2.8 & Agree \\
8 & Attitude of library staff & 2.9 & Agree \\
9 & Lack of fund for ICT acquisition & 3.0 & Agree \\
10 & Copyright issues affecting digitization & 2.8 & Agree \\
& Grand mean score & $\mathbf{3 . 0}$ & Agree \\
\hline
\end{tabular}

Table 1 showed the various challenges facing the use of web-based library services in Prof. Festus Aghagbo Nwako Library. The respondents strongly agreed that lack of awareness of available web-based services (3.3), poor internet coverage (3.3), high cost of internet services (3.4), unstable power supply (3.0), static and unattractive library website (3.0) and lack of fund for ICT equipment acquisition (3.0) among others were the major challenges facing the use of web-based library services.

The Table 2 showed that the respondents agreed on all the ten (10) outlined remedies for the challenges facing the use of web-based library services in Prof. Festus Aghagbo Nwako library. From the table creating awareness of available web-based services (3.8), expanding coverage and quality of internet services (3.6), organizing training programs for users (3.6), training of 
staff on ICT literacy (3.5), designing user friendly and dynamic website (3.4), acquiring ICT facilities (3.4) and use of creative commons licenses for online documents (3.3), among others were some of the major remedies that were strongly agreed by the respondents.

Table 2: Mean ratings on the strategies that could be used to remedy challenges to use of webbased services in Prof. Festus AghagboNwako library.

\begin{tabular}{llll}
\hline S/N & Remedies & Mean & Decision \\
\hline 1 & Creating awareness of available web-based services & 3.8 & Agree \\
2 & Expanding coverage and quality of internet services & 3.6 & Agree \\
3 & Organizing training program for users & 3.6 & Agree \\
4 & Sourcing for alternative means of funds for libraries & 3.2 & Agree \\
5 & Designing a strategic plan for marketing library services & 3.2 & Agree \\
6 & Designing user friendly and dynamic website & 3.4 & Agree \\
7 & Training of staff on ICT literacy & 3.5 & Agree \\
8 & Commercializing some library services for more funds & 2.9 & Agree \\
9 & Acquiring ICT facilities & 3.4 & Agree \\
10 & Use of creative common licenses for digital documents & 3.3 & Agree \\
& Grand mean score & $\mathbf{3 . 0}$ & Agree \\
\hline
\end{tabular}

\section{Discussion of Results}

The result generated from Research Question lof the study on the challenges facing the use of web-based library services in Prof. Festus Aghagbo Nwako library indicated that lack of awareness of available web-based library services was a major challenge to the use of the services. This shows that students were not aware of these services hence the need for academic libraries to market their web-based services. This is because library users today prefer the services they obtain online to those that requires them to be physically present. Kaur (2009) noted that web-based library services is a means of challenging the threat posed by the Internet and the WWW by using the library website to market and promote the library to its community. Therefore, the problem is no more that of distance or visiting the physical library building. It is that of awareness of the library website and the services obtainable in it.

Poor internet coverage and service was another major challenge. The poor state of internet service in the country and the lack of service coverage in some areas hinder effective use of library web services. This situation is so bad that even within the university premises such as some faculty buildings and students hostels, to receive good network service is difficult. This issue was noted by Fatoki (2005) who stated that most academic libraries in Nigeria are severely constrained by a number of factors that includes erratic internet services, lack of hardware and software and in most instances the nonavailability of the said ICTs in most academic libraries.
In addition, high cost of internet service and unstable power supply hindered the use of webbased library services. The cost of internet services and unstable power supply not only hinder the use of library's web services but also prevent the library from making them available in the first place. The cost charged by telecom companies in Nigeria for internet access is on the high side, this coupled with low funding of the library make internet access in the library a rare thing. Even when there is internet access, there is hardly power supply with which to access the internet, thereby causing the library to spend more money to run the generators.

Further, the static state and unattractive website of the library prevents the lack of enthusiasm on the part of the users to use it. The design of the library website is a major challenge, when it comes to provision and utilization of web-based library resources. This is because a poorly designed website will not only be unattractive to users but will also make it difficult to access and navigate the information resources. This agrees with Gbaje and Kotso (2014) who noted that poorly designed library website will not improve the visibility of the library neither will it promote what the library has to offer.

Other challenges to use of web-based library services includes, lack of computer literacy skill on the part of the users, lack of ICT facilities, Attitude of the library staff, lack of fund for ICT acquisition and Copyright issues.

The strategies as revealed by the findings that could be used to remedy the challenges facing the use of web-based services in Prof. Festus 
Aghagbo Nwako library, were that the library should create awareness of available web-based services through the marketing of the library services. According to Kaur (2009), marketing strategies does not just include telling the library clientele what collections and services are being offered but it also contributes to building relationship with library patrons that begins and ends with awareness of the library's users: their values, their concerns, and their needs; which will help in serving them better through the web.

The library should also look for an alternative means of funding. This will enable them provide better quality services to their users and compete effectively with other information providers. As noted by Abubakar (2011) that academic libraries should explore more alternative sources of funding as over reliance on the government on monies that are not forthcoming may not provide the desired solutions. New initiatives are required in the form of consultancy services, marketing of information products as well as other income generating services. Libraries need to generate or acquire more funds to tackle the problem of inadequate telecommunication gadgets, poor maintenance culture and high cost of computer hardware, etc.

Furthermore, they should ensure wide coverage and quality internet services. The university should get major telecom service providers to mount their service antenna within the campus. This will solve the problem of fluctuating and slow network services within the university.Other suggestions includes, organizing training programs for users and library staff on ICT literacy. Acquiring more ICT facilities and using creative commons licenses for their online documents to enable download without infringement of copyright agreements.

\section{Recommendations}

Based on the findings the following recommendations were made: the university authority should provide more funds to enable the library to fully upgrade its web-based services so that a true virtual experience could be derived from the use of these services. Library users need to be trained on the use of the library web services as sometimes these websites are a bit difficult to navigate. In the same vein the library needs to create user friendly websites so that users can easily access their web services.

\section{References}

Abubakar, B.M. (2011).Academic libraries in Nigeria in the 21st century.Library Philosophy and Practice.

Bhatnagar A. (2005)."Web-based library services", Proceedings of the 3rd Convention Planner. Assam University, Silchar, November 10-11, pp.426-434. Retrieved from http://dspace.inflibnet.ac.in/bitstream/1944/570/1 $127 \% 28 \mathrm{cal}+06 \% 29$.pdf $<8$

Fatoki, O.C. (2005). Prospects of GSM technology for academic library services.The Electronic Library, 23(3), 266-273

Gbaje, S.E.\& Kotso, J.A. (2014.Assessing the Content of Nigeria Academic Library Website.Information and Knowledge Management.4(7).

Kaur, K. (2009). Marketing the academic library on the web.Library Manage. 30(6/7), 454-468.

Madhusudhan M. \&Nagabhushabam V. (2012). Webbased library services in university libraries in India: An analysis of librarians' perspective. Electronic Library, 30(5), 569-588.

Nok, G. (2006). The challenges of computerizing a university library in Nigeria:The case of Kashim Ibrahim Library, Ahmadu Bello University, Zaria. Library Philosophy and Practice.

Ogunsola, L.A. \&Okusaga, T.O. (2008).Establishing virtual libraries in African universities: Problems and prospects.Ocean Journal of Social Science.1(1)

Okiy, R.B. (2005). Funding Nigerian libraries in the 21st century: will funding from alternative sources suffice? The BottomLine: Managing Library Finances, 18(2), 71-77

Swaminathan, N. (2012).Digital libraries: Their challenges and issues in the perspective ofdeveloping countries like India. In library and Information Science in developing countries. USA:IGI Global

Yetunde, Z.A. (2008). A study of internally generated revenue (IGR) by University Libraries in Nigeria.Borno Library, Archival and Information Science Journal, 7(1), 1-1 